\title{
Nitrate leaching in soybean rotations without nitrogen fertilizer
}

\author{
Ciro A. Rosolem • Gustavo Castoldi • \\ Laércio A. Pivetta • Tyson E. Ochsner
}

Received: 24 March 2017 / Accepted: 10 November 2017 / Published online: 18 November 2017

(C) Springer International Publishing AG, part of Springer Nature 2017

\begin{abstract}
Background Nitrate leaching is a primary pathway of nitrogen loss from agricultural systems, and is affected by both tillage and cropped species. However, there is little information on conservation systems without nitrogen fertilization.

Methods Nitrate leaching was assessed in soybean (Glycine max) cropped in rotation with the following cover crops under no-till and chiseling: ruzigrass (Brachiaria ruziziensis), grain sorghum (Sorghum bicolor), pearl millet (Pennisetum glaucum), forage sorghum (Sorghum bicolor), Sunn hemp (Crotalaria juncea), triticale (X Triticosecale) and sunflower (Helianthus annuus).

Results Ruzigrass and grain sorghum cropped in the fall/winter resulted in similar $\mathrm{NO}_{3}{ }^{-}$leaching, which was greater under sunflower than under triticale, likely due to high $\mathrm{N}$ uptake and immobilization in plant residues. Sunn hemp as a spring crop resulted in higher $\mathrm{NO}_{3}{ }^{-}$leaching than pearl millet at two locations and forage sorghum at one location likely due to a higher $\mathrm{N}$ input by biological fixation. Millet resulted in the lowest $\mathrm{N}$ leaching by depleting the soil solution. Chiseling/ fallow resulted in higher nitrogen leaching as compared with non-fixing $\mathrm{N}$ cover crops.
\end{abstract}

Responsible Editor: W Richard Whalley.

C. A. Rosolem $(\bowtie) \cdot$ G. Castoldi $\cdot$ L. A. Pivetta •

T. E. Ochsner

São Paulo State University, College of Agricultural Sciences, Botucatu, SP, Brazil

e-mail: rosolem@fca.unesp.br
Conclusions Even when $\mathrm{N}$ is not applied, it is important to intensify cropping systems in tropical environments using cover crops with vigorous root systems and high $\mathrm{N}$ demand, which prevent $\mathrm{N}$ leaching, as well as provides $\mathrm{N}$ to the following crop as the straw is mineralized.

Keywords Nitrate $\cdot$ Sunn hemp · Grain sorghum $\cdot$ Pearl millet $\cdot$ Drainage $\cdot$ No-till

\section{Introduction}

Soil nitrate $\left(\mathrm{NO}_{3}{ }^{-}\right)$available to plants is available for leaching as well (Errebhi et al. 1998). Nitrogen (N) leaching is affected by water flow in the soil and by $\mathrm{NO}_{3}{ }^{-}$concentration in the soil solution, which is increased with nitrogen fertilizer application, one of the main factors affecting $\mathrm{N}$ loss from the system (Sexton et al. 1996; Fernandes and Libardi 2009). However, leaching of the $\mathrm{N}$ derived from fertilizer, although proportional to the rate applied, may be small (Fernandes and Libardi 2009), amounting to 5\% in a Yellow Red Latosol cropped with sugarcane (Ghiberto et al. 2011). The amount of $\mathrm{N}$ lost by leaching also varies with the rate of soil $\mathrm{N}$ mineralization and immobilization by plants and microorganisms and with rainfall (Fernandes et al. 2006; Perego et al. 2012). Soil organic matter (SOM) mineralization of may be responsible for a large part of the $\mathrm{N}$ leached in some agricultural cropping systems (Schneider and Haider 1992; Fernandes and Libardi 2009; Ghiberto et al. 2011). 
In systems with little or no $\mathrm{N}$ input via fertilizer, SOM and plant residue mineralization are the main factors determining soil $\mathrm{N}$ availability, and consequently the amount of $\mathrm{N}$ prone to nitrification. This is the case of several soybean production systems in the world, where soybean is grown in the spring/summer and throughout the fall/winter season the soil remains uncropped or is cropped to cover crops - which are commonly not fertilized. Nitrate leaching at a rate of $23 \mathrm{~kg} \mathrm{ha}^{-1} \mathrm{y}^{-1}$ has been measured under a no-till (NT) corn-soybean rotation in the savanna region of Brazil (Wilcke and Lilienfein 2005), but little is known about leaching rates under unfertilized soybean systems, mainly in tropical regions.

The introduction of cover crops that reduce $\mathrm{N}$ leaching is important to increase $\mathrm{N}$ use efficiency and system sustainability (Ochsner et al. 2010; Perego et al. 2012). Cover crops can help to prevent $\mathrm{N}$ losses by taking up high amounts of $\mathrm{N}$ or by having $\mathrm{C} / \mathrm{N}$ ratios that balance $\mathrm{N}$ mineralization and immobilization resulting in a better synchrony of mineralization with $\mathrm{N}$ uptake by the subsequent crop (Lara Cabezas et al. 2004). Grasses may prevent losses by taking $N$ up and immobilizing it in the biomass. On the other hand, legume cover crops add $\mathrm{N}$ to the system, which could offset losses. Sometimes, however, to prevent $\mathrm{N}$ losses from systems with high inputs of $\mathrm{N}$ by biological fixation, the inclusion of a catch crop might be a good strategy to prevent nitrate leaching (Askegaard et al. 2005).

No-till is an important soil conservation practice. However, few producers adopt a diversified cropping system, another hallmark of conservation agriculture. The over-reliance on soybean production, which can result in inadequate crop residue to protect the soil structure, has led to excessive soil compaction in many areas. A strategy to manage soil compaction is chiseling, because it has less disruptive power as compared with disking, while maintaining higher amounts of crop residues on the surface (Williams et al. 2000). However, chiseling effects are ephemeral, so it may be better to use diversified crop rotations including species with vigorous root systems able to grow in soils with high penetration resistance, creating stable pores through which roots of the subsequent crop can grow (Silva and Rosolem 2002). While both cover crops and chiseling can potentially contribute to improvements in soil structure, they may have different effects on nitrate leaching, which is a primary pathway of $\mathrm{N}$ loss from the soil-plant system. No-till can result in lower $\mathrm{NO}_{3}{ }^{-}$leaching compared with conventional tillage due to a lower organic matter mineralization rate and/or a higher denitrification (Mkhabela et al. 2008). In other cases, lower $\mathrm{NO}_{3}{ }^{-}$ leaching under NT as compared with chiseling is due to increased water flow at depth and increased $\mathrm{NO}_{3}{ }^{-}$ concentration in the soil solution under chiseling (Rekha et al. 2011). However, sometimes NT may not decrease $\mathrm{N}$ leaching (Hansen et al. 2015) or even cause greater losses of $\mathrm{N}$ compared with conventional tillage due to the network of biopores in the soil profile under NT (Paul and Clark 1989).

It is clear that both cover crops and chiseling may have beneficial effects on soil physical properties under intensive NT soybean production. However, the effects of chiseling and cover crops with deep, vigorous root systems on $\mathrm{NO}_{3}{ }^{-}$leaching from these cropping systems has not been well documented. The objective of this study was to evaluate the effect of chiseling and cover crops grown in rotation with NT soybeans on N loss by leaching, in two long term experiments, in the absence of $\mathrm{N}$ fertilization.

\section{Material and methods}

Evaluations were carried out from April 2012 to April 2013 in two long term experiments in Botucatu, São Paulo, Brazil, located at $22^{\circ} 49^{\prime} \mathrm{S}$ and $48^{\circ} 25^{\prime} \mathrm{W}$, at $786 \mathrm{~m}$ altitude and the slope is less than $3 \%$. The study area is in a transition of two soil types: a clay Rhodic Hapludox and clay Typic Rhodudalf (Soil Survey Staff 2014), where two experiments have been carried out. The climate of the region, according to Köppen's classification, is Cwa (mesothermic with dry winter climate). The dry season is well defined from May to September. The average annual precipitation is $1514 \mathrm{~mm}$; the average temperature in the hottest month is above $22{ }^{\circ} \mathrm{C}$ and in the coldest month between 3 and $18{ }^{\circ} \mathrm{C}$ (Cunha and Martins 2009). Rainfall and average air temperature data during the experimental period (Fig. 1) were obtained from a meteorological station close to the experiments.

In both studies, the experimental design was a splitplot in complete randomized blocks with four replicates. In the Rhodic Hapludox, the following treatments have been used since 2006: the main plots consisted of grain sorghum (Sorghum bicolor (L.) Moench) and ruzigrass (Brachiaria ruziziensis Germain et. Evrard) cropped alone or intercropped, grown in the fall/winter; Pearl 


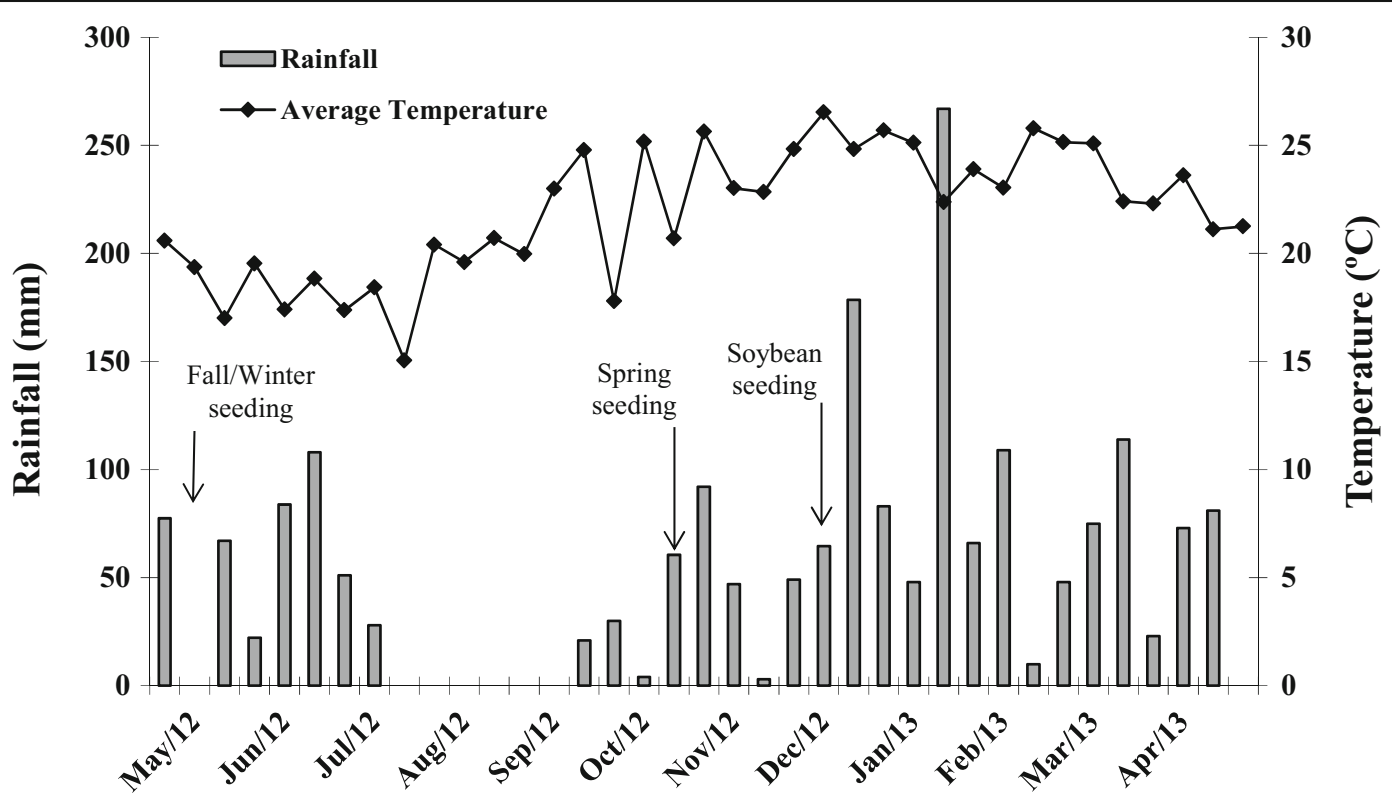

Fig. 1 Decendial rainfall and average temperature from May 2012 to April 2013. Experimental Farm Lageado, Crop Science College, Botucatu, SP, Brazil

millet (Pennisetum americanum (L.) Leek), Sunn hemp (Crotalaria juncea L.), or forage sorghum (Sorghum bicolor (L.) Moench) were grown in subplots $(5 \times$ $10 \mathrm{~m}$ each) in the spring; and soybean (Glycine max (L.) Merrill) was grown in all subplots in the summer. Grain sorghum and soybean were harvested for grain. Ruzigrass, pearl millet, forage sorghum and Sunn hemp were grown as cover crops, being desiccated with herbicide just before planting the subsequent crop.

In the Typic Rhodudalf the following treatments have been applied since 2003: plots were cropped in the fall/ winter to triticale (Triticosecale Wittmack) and sunflower (Helianthus annuus L.); and the subplots $(5 \times 8 \mathrm{~m}$ each) in the spring to pearl millet, forage sorghum and Sunn hemp; the chiseling/fallow treatment was set in the subplots as well. Chiseling was performed in spring 2003 and 2009 at a working depth of $0.30 \mathrm{~m}$, and these plots were kept fallow. In the summer, soybean was grown in all subplots. The fall/winter crops were grown to maturity and harvested, and the spring crops were terminated early with herbicide before soybean sowing. Cropping sequence and crop rotations are listed in Table 1, and some chemical and textural characteristics of the soils are shown in Table 2.

Nitrate leaching was estimated from May 01, 2012 (planting of fall/winter crops) to April 26, 2013 (10 days after 2012/13 soybean harvest), and was calculated based on $\mathrm{NO}_{3}{ }^{-}$concentrations in the soil solution collected at
$0.8 \mathrm{~m}$ depth and on estimated drainage below $0.8 \mathrm{~m}$. Soil solution was collected through ceramic cup extractors, adapted from Reichardt et al. (1977), installed in the center of each subplot $80-\mathrm{cm}$ deep. After each rainfall $>3 \mathrm{~mm}$, soil solution was extracted by applying vacuum equivalent to $-60 \mathrm{kPa}$ to the ceramic extractors. The time between vacuum application and soil solution collection was one day. Soil solution samples were collected for a total of 25 days during the experiment and stored in plastic tubes under refrigeration, and $\mathrm{NO}_{3}{ }^{-}$was determined by ultraviolet absorption spectrophotometry (Eaton et al. 1993).

Water drainage below $80-\mathrm{cm}$ was calculated using the water balance method (Allen et al. 1998), according to the following equation:

$D=R-E T-\Delta S-R O$

where $\mathrm{D}$ is the water drainage $(\mathrm{mm}), \mathrm{R}$ is the rainfall $(\mathrm{mm})$, ET is the evapotranspiration $(\mathrm{mm}), \Delta \mathrm{S}$ is the variation in soil water storage down $80 \mathrm{~cm}$ deep (mm) and RO is the surface runoff ( $\mathrm{mm}$ ).

Water storage in the soil profile was monitored using a capacitance probe (Diviner 2000®, Sentek Pt Ltd., Australia 2009) inserted in an access tube installed in each subplot. The capacitance probe measures the volumetric soil moisture at different soil profile points (every $10 \mathrm{~cm}$ up to $80 \mathrm{~cm}$ deep). Measurements were taken periodically, and the time interval between two consecutive 
Table 1 Carbon and nitrogen contents, $\mathrm{pH}$, bulk density and particle size distribution of the soils by the beginning of the experiments, in April 2012 (the values are the mean of all the treatments)

\begin{tabular}{|c|c|c|c|c|c|c|c|c|c|}
\hline \multicolumn{2}{|c|}{ Soil characteristic } & \multicolumn{4}{|c|}{ Rhodic Hapludox } & \multicolumn{4}{|c|}{ Typic Rhodudalf } \\
\hline & & \multicolumn{8}{|c|}{ Soil layer, m } \\
\hline & & $0.0-0.2$ & $0.2-0.4$ & $0.4-0.6$ & $0.6-0.8$ & $0.0-0.2$ & $0.2-0.4$ & $0.4-0.6$ & $0.6-0.8$ \\
\hline $\mathrm{pH}^{\mathrm{a}}$ & $\mathrm{g} \mathrm{kg}^{-1}$ & 4.95 & 4.10 & 3.80 & 3.70 & 4.30 & 4.00 & 3.95 & 3.85 \\
\hline TOC $^{\mathrm{b}}$ & $\mathrm{g} \mathrm{kg}^{-1}$ & 21.4 & 15.6 & 17.3 & 19.9 & 18.1 & 13.5 & 13.8 & 15.1 \\
\hline Total-N & $\mathrm{g} \mathrm{kg}^{-1}$ & 1.5 & 1.0 & 0.9 & 0.9 & 1.8 & 1.4 & 1.1 & 1.0 \\
\hline Bulk density & $\mathrm{g} \mathrm{cm}^{-3}$ & 1.55 & 1.52 & 1.40 & 1.32 & 1.37 & 1.31 & 1.27 & 1.26 \\
\hline Sand & $\mathrm{g} \mathrm{kg}^{-1}$ & 488 & 413 & 375 & 388 & 104 & 84 & 66 & 75 \\
\hline Clay & $\mathrm{g} \mathrm{kg}^{-1}$ & 430 & 505 & 505 & 510 & 655 & 705 & 730 & 730 \\
\hline Silt & $\mathrm{g} \mathrm{kg}^{-1}$ & 83 & 82 & 120 & 102 & 241 & 211 & 204 & 195 \\
\hline
\end{tabular}

${ }^{\mathrm{a}} \mathrm{pH}$ in $\mathrm{CaCl}_{2} ;{ }^{\mathrm{b}}$ Total Organic Carbon

measurements was dependent on rainfall. Measurements were taken on the first, second and third days after each rainfall. As the soil dried, the time interval between measurements increased. Soil water storage measurements were recorded on a total of 112 dates and the variation in soil water storage was calculated for every period between consecutive readings.

Rainfall, average temperature, wind speed, relative humidity, and solar radiation were obtained from a meteorological station within $1000 \mathrm{~m}$. Evapotranspiration from a grass reference surface $\left(\mathrm{ET}_{0}\right)$ was calculated following FAO-56 (Allen et al. 1998). Actual evapotranspiration (ET, in mm) was estimated using the FAO-56 dual crop coefficient method (Allen et al. 1998) according to the equation:

$E T=\left(K_{s} K_{c b}+K_{e}\right) E T_{0}$

where $K_{\mathrm{s}}$ is the water stress coefficient (non-dimensional), $K_{\mathrm{cb}}$ is the basal crop coefficient, and $K_{\mathrm{e}}$ is the soil evaporation coefficient (non-dimensional). These three coefficients were calculated daily based on crop development stage, water content at $10 \mathrm{~cm}$ depth (first measure of capacitance probe), and soil water content of the root zone according to FAO-56 (Allen et al. 1998).

The coefficient $K_{s}$ is used to adjust $K_{c b}$ as water availability decreases; hence, this percentage varies by crop according to tabulated values (Allen et al. 1998). The $K_{e}$ ranged from 1.2 (fully wet and bare soil) to 0.0 (soil top layer dry and/or fully covered). The $K_{c b}$ values for each development stage of soybean, grain sorghum, forage sorghum and millet were used according to tabulated values (Allen et al. 1998). For Sunn hemp and triticale, the $K_{c b}$ of chickpeas and wheat were used, respectively. For ruzigrass and ruzigrass + grain sorghum, the $K_{\mathrm{cb}}$ values obtained by Andrade Júnior et al. (2010) were used.

Surface runoff was calculated using the modified runoff curve number method, as suggested by Soltani and Sinclair (2012). In that method, the soil water

Table 2 Annual cropping sequence used in the experiment

\begin{tabular}{llll}
\hline Soil & $\begin{array}{l}\text { Fall / Winter (Plots) } \\
\text { April - Sept. }\end{array}$ & $\begin{array}{l}\text { Spring (Subplots) } \\
\text { Sept./Oct. }- \text { Dec. }\end{array}$ & $\begin{array}{l}\text { Summer } \\
\text { Dec. }- \text { March }\end{array}$ \\
\hline Rhodic Hapludox (since 2006) & Grain sorghum & Pearl millet \\
& Ruzigrass & Sunn hemp \\
Typic Rhodudalf (since 2003) & Grain sorghum + Ruzigrass & Forage sorghum \\
& Triticale & Pearl millet & Sunn hemp \\
& Sunflower & Forage sorghum \\
& & Fallow / Chiseling
\end{tabular}

${ }^{\text {a }}$ Chiseling was performed in Spring 2003 and 2009 
content - along with soil texture and relief - is a determining factor in runoff, which increases with soil water saturation. The coefficient that determines the effect of water content on surface runoff (SWRN) (Ritchie 1998) is presented in Eq. 3:

$S W R N=0.15 \cdot\left[\frac{S W C_{s a t}-S W C_{t o t a l}}{S W C_{s a t}-S W C_{w p}}\right]$

where $\mathrm{SWC}_{\mathrm{sat}}$ is volumetric soil water content at saturation (represented by soil porosity), $\mathrm{SWC}_{\text {total }}$ is the actual volumetric soil water content, $\mathrm{SWC}_{\mathrm{wp}}$ is the volumetric soil water content at wilting point (determined at $-1500 \mathrm{kPa}$ by pressure plate). The following factor was used to determine surface runoff (RO), in $\mathrm{mm}$ (Eq. 4) (Soil Conservation Service 1985).

$$
\begin{gathered}
\text { if rainfall }>S W R N \cdot S, \quad R O=\frac{(\text { Rainfall }-S W R N \cdot S)^{2}}{\text { Rainfall }+0.8 \cdot S} \\
\text { if rainfall } \leq S W R N \cdot S, \quad \begin{array}{c}
R O=0
\end{array}
\end{gathered}
$$

where $S$ is the retention parameter related to the soil curve number $(\mathrm{CN})$ by $S=254 *(100 / \mathrm{CN}-1)$.

Soil $\mathrm{CN}$ ranges from 0 , when there is no run-off, to 100 , which represents runoff of total rainfall. In the present study, a CN of 20 (Rhodic Hapludox) and 40 (Typic Rhodudalf) were used. The $\mathrm{CN}$ values were estimated by the approximate average of runoff curve numbers for a condition with permanent cover (pasture) (Soil Conservation Service 1985) (39 to Rhodic Hapludox and 61 to Typic Rhodudalf) and the runoff coefficients estimated to Brazilian soils (Lombardi Neto et al. 1994) (10\% to Rhodic Hapludox and 20\% to Typic Rhodudalf). The $\mathrm{CN}$ were low because the experiments were under no-tillage, the terrains were flat and the soils have high water infiltration rate, as described by Prando et al. (2010) for the Rhodic Hapludox.

The amount of $\mathrm{N}$ leached between each pair of solution sampling dates was estimated by multiplying the average $\mathrm{NO}_{3}{ }^{-}$concentration in the soil solution by the estimated water drainage below $0.80 \mathrm{~m}$, according to the following equation:

$\mathrm{NO}_{3}^{-}-\mathrm{N}$ leached $\left(\mathrm{kgha}^{-1}\right)=\frac{\mathrm{D} \cdot\left[\mathrm{NO}_{3}^{-}\right] \cdot 0.226}{100}$

where $D$ is the water drainage below $80 \mathrm{~cm}$ (sum of $D$ values obtained between two consecutive samplings of soil solution, in $\mathrm{mm}),\left[\mathrm{NO}_{3}\right]$ is the nitrate concentration in soil solution (average of two consecutive samplings, in $\mathrm{mg}$
$\left.\mathrm{L}^{-1}\right), 0.226$ is the conversion factor of $\mathrm{mg} \mathrm{NO}_{3}{ }^{-}$into $\mathrm{mg}$ $\mathrm{N}$, and 100 is the conversion factor to obtain $\mathrm{kg} \mathrm{ha}^{-1}$.

Samples of the remaining plant residues on the soil surface were taken after the previous soybean harvest (April 2012), after the harvest of the fall/winter crop (September 2012), and after chemical desiccation of the spring cover crops (early December 2012). Samples were collected from three random points per subplot, using a $0.5 \times 0.5 \mathrm{~m}$ wooden frame. The material was stored in paper bags and dried to constant weight in a forced air oven at $60^{\circ} \mathrm{C}$. The samples were then ground in a Wiley mill and sieved through a $1 \mathrm{~mm}$ mesh. Total $\mathrm{N}$ and $\mathrm{C}$ were determined in an automated elemental analyzer (TruSpec ${ }^{\text {TM }}$ CHNS, LECO®) (Swift 1996).

Treatment effects were analyzed using ANOVA. When significant differences were found ( $\mathrm{F}$ test, $P<0.05$ ), means were compared using $t$ test (LSD, $\mathrm{P}<0.05$ ), except for the main plots in Typic Rhodudalf, in which means were compared by $\mathrm{F}$ test $(\mathrm{P}<0.05)$. The $\mathrm{NO}_{3}{ }^{-}$concentrations in the soil solution were compared for each sampling time.

\section{Results}

Rhodic Hapludox

The highest $\mathrm{N}$ accumulation in soybean residue following the 2011/12 harvest was observed in plots with ruzigrass as a fall/winter crop, and in subplots with Sunn hemp grown in the spring (Table 3). For the fall/winter crops, the amount of $\mathrm{N}$ accumulated in ruzigrass residue was greater than that of ruzigrass + grain sorghum and grain sorghum. All fall/winter crops accumulated more $\mathrm{N}$ in systems where forage sorghum was grown in the spring. Among the spring crop residues, Sunn hemp - the only legume grown in the spring - had the highest $\mathrm{N}$ amount. The $\mathrm{N}$ in spring crops residues was also strongly affected by fall/winter crops, since it was higher when Sunn hemp, millet and forage sorghum were grown after ruzigrass. No significant interaction was observed between fall/winter and spring crops.

There was no interaction of fall/winter and spring crops for total $\mathrm{N}$ leaching, drainage and nitrate concentration in the soil solution. Total $\mathrm{N}$ loss via $\mathrm{NO}_{3}{ }^{-}$ leaching was higher in systems cropped to Sunn hemp and forage sorghum in the spring (Table 4). In these rotations, total $\mathrm{N}_{-} \mathrm{NO}_{3}{ }^{-}$leaching reached 33.6 and $32.2 \mathrm{~kg} \mathrm{ha}^{-1}$, respectively, almost twice the value observed in the system with pearl millet. No significant 
Table 3 Nitrogen accumulated in the residues of soybean, Fall/Winter and Spring crops as affected by Fall/Winter and Spring treatments, in the Rhodic Hapludox and Typic Rhodudalf

\begin{tabular}{|c|c|c|c|}
\hline Rhodic hapludox & $\begin{array}{l}\text { Soybean } \\
2011 / 12\end{array}$ & $\begin{array}{l}\text { Fall/Winter } \\
2012\end{array}$ & $\begin{array}{l}\text { Spring } \\
2012\end{array}$ \\
\hline Fall/Winter (Plots) & $\mathrm{kg} \mathrm{ha}^{-1}$ & & \\
\hline Ruzigrass & $29.7 \mathrm{a}$ & $82.4 \mathrm{a}$ & $108.8 \mathrm{a}$ \\
\hline Grain Sorghum & $23.7 \mathrm{~b}$ & $15.7 \mathrm{c}$ & $56.6 \mathrm{c}$ \\
\hline Ruzigrass + Grain Sorghum & $21.4 \mathrm{~b}$ & $59.9 \mathrm{~b}$ & $93.9 \mathrm{~b}$ \\
\hline \multicolumn{4}{|l|}{ Spring (Subplots) } \\
\hline Sunn Hemp & $31.0 \mathrm{a}$ & $54.2 \mathrm{~b}$ & $120.3 \mathrm{a}$ \\
\hline Pearl Millet & $19.8 \mathrm{~b}$ & $44.1 \mathrm{c}$ & $60.0 \mathrm{c}$ \\
\hline Forage Sorghum & $23.9 \mathrm{~b}$ & $59.6 \mathrm{a}$ & $79.1 \mathrm{~b}$ \\
\hline CV Fall/Winter (\%) & 14.9 & 11.2 & 7.6 \\
\hline CV Spring (\%) & 26.5 & 10.5 & 16.8 \\
\hline Typic rhodudalf & $\begin{array}{l}\text { Soybean } \\
2011 / 12\end{array}$ & $\begin{array}{l}\text { Fall/Winter } \\
2012\end{array}$ & $\begin{array}{l}\text { Spring } \\
2012\end{array}$ \\
\hline Fall/Winter (Plots) & $\mathrm{kg} \mathrm{ha}^{-1}$ & & \\
\hline Sunflower & $47.5 \mathrm{a}$ & $17.3 \mathrm{a}$ & $45.9 \mathrm{a}$ \\
\hline Triticale & $47.1 \mathrm{a}$ & $18.6 \mathrm{a}$ & $38.8 \mathrm{~b}$ \\
\hline \multicolumn{4}{|l|}{ Spring (Subplots) } \\
\hline Pearl Millet & $38.8 \mathrm{~b}$ & $18.7 \mathrm{a}$ & $28.7 \mathrm{~b}$ \\
\hline Forage Sorghum & $41.3 \mathrm{~b}$ & $20.2 \mathrm{a}$ & $49.7 \mathrm{ab}$ \\
\hline Sunn Hemp & $64.4 \mathrm{a}$ & $17.9 \mathrm{a}$ & $61.3 \mathrm{a}$ \\
\hline Fallow / Chiseling & $44.7 \mathrm{~b}$ & $14.9 \mathrm{a}$ & $29.5 \mathrm{~b}$ \\
\hline CV Fall/Winter (\%) & 32.5 & 63.0 & 9.3 \\
\hline CV Spring (\%) & 32.0 & 31.9 & 31.8 \\
\hline
\end{tabular}

Means followed by different letters differ significantly by $\mathrm{t}$ test (LSD) at $5 \%$ probability. $\mathrm{CV}=$ coefficient of variation

differences in $\mathrm{NO}_{3}{ }^{-}$leaching were observed among fall/ winter crops, and the total average $\mathrm{N}_{-} \mathrm{NO}_{3}{ }^{-}$leaching was $22.4 \mathrm{~kg} \mathrm{ha}^{-1}$.

Soil water drainage varied widely throughout the year, but showed only small variations between cropping systems (Fig. 2). A long period with successive negative drainage values (upward water movement) was observed in the winter as result of the lack of rainfall and root growth in the soil profile, what generated the matric potential gradient. In contrast, five peaks were observed - resulting from heavy rains occurring at the beginning of winter and during summer - with high drainage values $(>60 \mathrm{~mm})$. These peaks were primarily responsible for the high total drainage values throughout the year, which ranged from 625 to $676 \mathrm{~mm}$ (Table 4).

Two periods with high $\mathrm{NO}_{3}{ }^{-}$concentrations in soil solution were observed: the first in early winter, and the second late in the spring crops (Fig. 3). In the first period,
Table 4 Total loss of nitrogen as nitrate $\left(\mathrm{NO}_{3}{ }^{-}-\mathrm{N}\right)$ leaching and cumulative water drainage as affected by Fall/Winter cultivation and Spring treatments, in the Rhodic Hapludox and Typic Rhodudalf

\begin{tabular}{|c|c|c|}
\hline Rhodic Hapludox & $\begin{array}{l}\mathrm{NO}_{3}{ }^{-}-\mathrm{N} \text { leaching } \\
\mathrm{kg} \mathrm{ha}^{-1} \text { year }^{-1}\end{array}$ & $\begin{array}{l}\text { Drainage } \\
\mathrm{mm}\end{array}$ \\
\hline \multicolumn{3}{|l|}{ Fall/Winter (Plots) } \\
\hline Ruzigrass & $27.0 \mathrm{a}$ & $626 \mathrm{~b}$ \\
\hline Grain Sorghum & $26.8 \mathrm{a}$ & $676 \mathrm{a}$ \\
\hline Ruzigrass + Grain Sorghum & $30.4 \mathrm{a}$ & $625 \mathrm{~b}$ \\
\hline \multicolumn{3}{|l|}{ Spring (Subplots) } \\
\hline Sunn Hemp & $33.6 \mathrm{~b}$ & $647 \mathrm{a}$ \\
\hline Pearl Millet & $18.4 \mathrm{a}$ & $644 \mathrm{a}$ \\
\hline Forage Sorghum & $32.2 \mathrm{~b}$ & $636 \mathrm{~b}$ \\
\hline CV Fall/Winter (\%) & 15.9 & 0.33 \\
\hline CV Spring (\%) & 19.2 & 0.92 \\
\hline Typic Rhodudalf & $\begin{array}{l}\mathrm{NO}_{3}{ }^{-}-\mathrm{N} \text { leaching } \\
\mathrm{kg} \mathrm{ha}^{-1} \text { year }^{-1}\end{array}$ & $\begin{array}{l}\text { Drainage } \\
\mathrm{mm}\end{array}$ \\
\hline \multicolumn{3}{|l|}{ Fall/Winter (Plots) } \\
\hline Sunflower & $27.0 \mathrm{a}^{\circ}$ & $555 \mathrm{a}$ \\
\hline Triticale & $16.6 \mathrm{~b}$ & $556 \mathrm{a}$ \\
\hline \multicolumn{3}{|l|}{ Spring (Subplots) } \\
\hline Pearl Millet & $15.3 \mathrm{c}$ & $550 \mathrm{~b}$ \\
\hline Forage Sorghum & $18.7 \mathrm{bc}$ & $533 \mathrm{c}$ \\
\hline Sunn Hemp & $32.6 \mathrm{a}$ & $546 \mathrm{~b}$ \\
\hline Fallow / Chiseling & $20.5 \mathrm{~b}$ & $595 \mathrm{a}$ \\
\hline CV Fall/Winter & 35.9 & 1.0 \\
\hline CV Spring & 15.4 & 1.0 \\
\hline
\end{tabular}

Means followed by different letters differ significantly by $t$ test (LSD) at $5 \%$ probability. $\mathrm{CV}=$ coefficient of variation. ${ }^{\circ}$ significantly different at $8 \%$ probability

the higher $\mathrm{NO}_{3}{ }^{-}$peak in soil solution was observed under ruzigrass (Fig. 3a) and Sunn hemp (Fig. 3b). This finding was most likely related to the higher amount of $\mathrm{N}$ in soybean residue present in these plots and subplots. The second period started at the end of November and extended until February, from the end of the spring crop through half the soybean cycle. Some differences were observed during this period between plots that had different fall/winter crops (Fig. 3a). Higher $\mathrm{NO}_{3}{ }^{-}$concentrations were observed in plots where ruzigrass + grain sorghum was previously grown compared with plots where ruzigrass was grown alone in the fall/winter. For spring crops, the lowest $\mathrm{NO}_{3}{ }^{-}$concentration in soil solution was observed for pearl millet (Fig. 3b). Rotations including Sunn hemp and forage sorghum showed a peak in $\mathrm{NO}_{3}{ }^{-}$concentration in soil solution in January 2013, whereas in subplots with 
Fig. 2 Water drainage below $0.8 \mathrm{~m}$ depth affected by fall/winter cultivation (a) and spring cultivation (b), in the Rhodic Hapludox
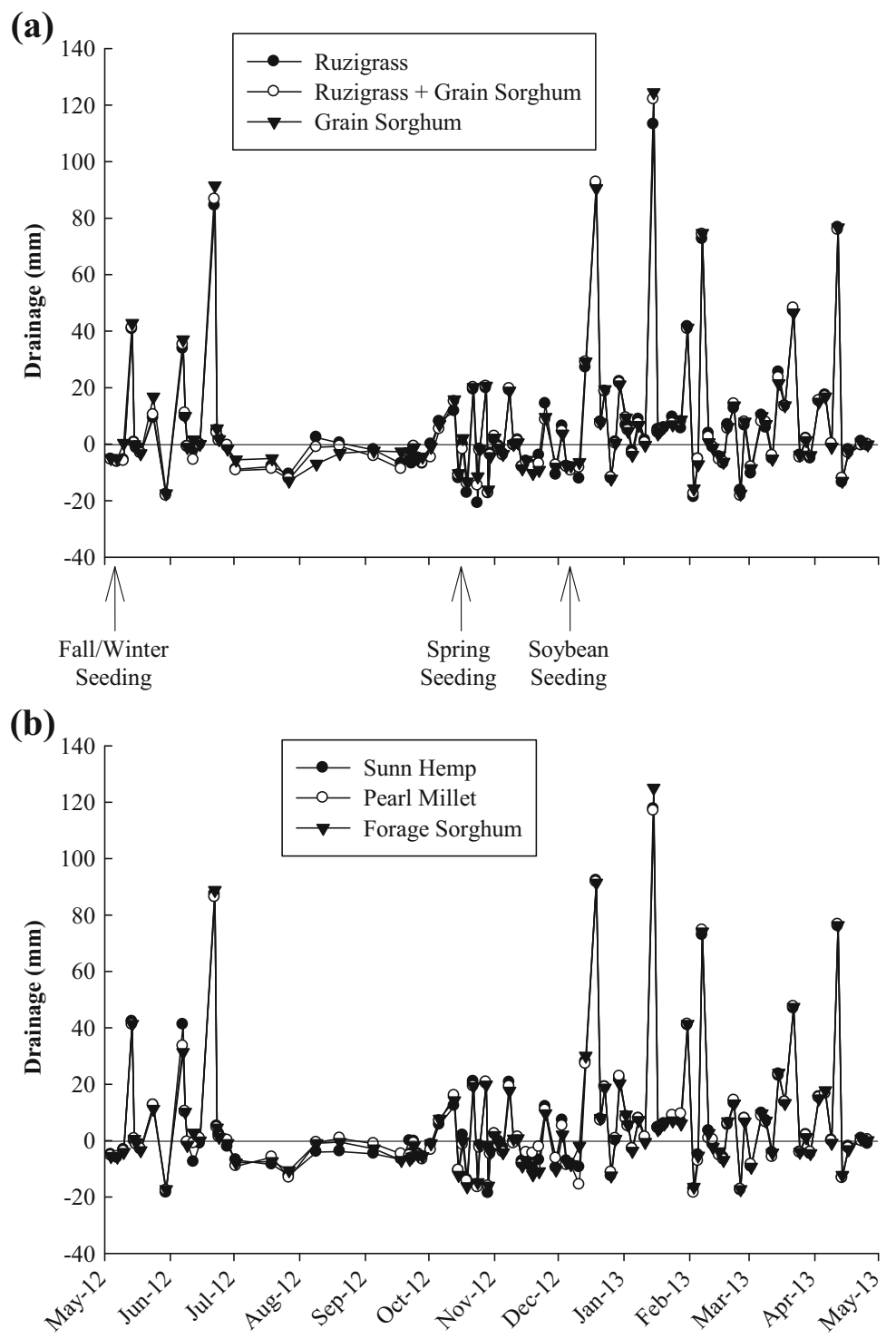

millet the highest $\mathrm{NO}_{3}{ }^{-}$concentration in soil solution for the same period was only $14 \mathrm{mg} \mathrm{L}^{-1}$. This low concentration under pearl millet might be the primary cause for the low total $\mathrm{NO}_{3}{ }^{-}$leaching in that cropping system (Table 4).

\section{Typic Rhodudalf}

There was no significant interaction of fall/winter and spring managements for any variable. Accumulated $\mathrm{N}$ in plant residues after soybean in April 2012 was not affected by fall/winter crops, but it was higher when soybean followed Sunn hemp (Table 3), due to a higher N concentration in plant residues (data not shown), since straw dry matter was similar (data not shown) between treatments. There were no significant differences in plant residue $\mathrm{N}$ accumulation after the fall/winter crops (Table 3). The $\mathrm{N}$ accumulation in plant residues after the spring crops was higher in rotation with sunflower than triticale, due to a lower $\mathrm{N}$ immobilization by sunflower. Among the spring crops, $\mathrm{N}$ accumulation in plant residues was higher under Sunn hemp than pearl millet and chiseling/fallow (Table 3), mainly due to the higher $\mathrm{N}$ concentration of the legume (data not shown). Although the seasons were not statistically compared, accumulated $\mathrm{N}$ decreased from soybean to fall/winter, due to the higher $\mathrm{N}$ concentration and low $\mathrm{C} / \mathrm{N}$ ratio of soybean residues, which were 
Fig. 3 Nitrate $\left(\mathrm{NO}_{3}{ }^{-}\right)$ concentration in the soil solution affected by Fall/Winter cultivation (a) and Spring cultivation (b), in the Rhodic Hapludox. Vertical bars indicate the least significant difference (LSD) comparing crops $(P<0.05)$
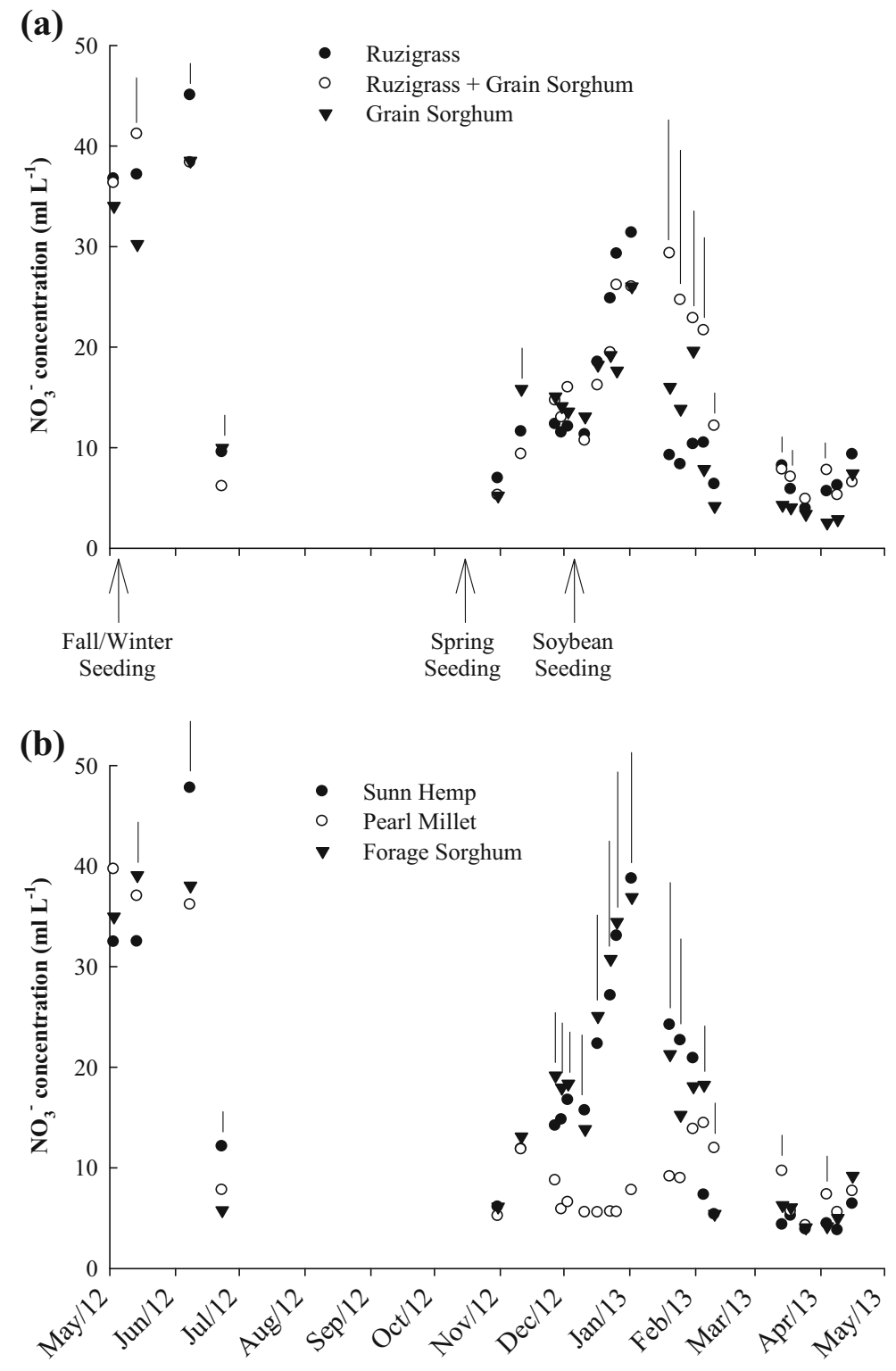

mineralized, and its $\mathrm{N}$ used and exported by fall/winter crops. The accumulated $\mathrm{N}$ in plant residues increased from fall/winter to spring due to the growth of cover crops and weeds (fallow subplots), which were not harvested. It is worth observing that even the weeds were able to accumulate $\mathrm{N}$ at the chiseling/fallow subplots.

Accumulated drainage for approximately one year averaged $556 \mathrm{~mm}$ (Table 4), corresponding to $29 \%$ of the cumulative rainfall $(1906 \mathrm{~mm})$. The time series of drainage during the year were similar across the different fall/winter and spring treatments (Fig. 4). However, among the spring managements, cumulative drainage was highest with chiseling/fallow. Nitrate leaching was highest for Sunn hemp and lowest for millet (Table 4). The $\mathrm{NO}_{3}-\mathrm{N}$ concentrations in the soil solution were higher with sunflower as compared with triticale from June to early December (Fig. 5a), whereas the highest concentration among the spring treatments was found with Sunn hemp throughout much of the year (Fig. 5b). Chiseling/fallow resulted in the lowest $\mathrm{N}$ concentrations in the soil solution from May until mid-November, but equaled Sunn hemp from midDecember to mid-January (Fig. 5b). Nitrogen concentrations were similar between sorghum and pearl millet for most sampling periods, in contrast to the results at the 
Fig. 4 Drainage below $0.8-\mathrm{m}$ depth as affected by fall/winter (a) and spring (b) treatments, in the Typic Rhodudalf

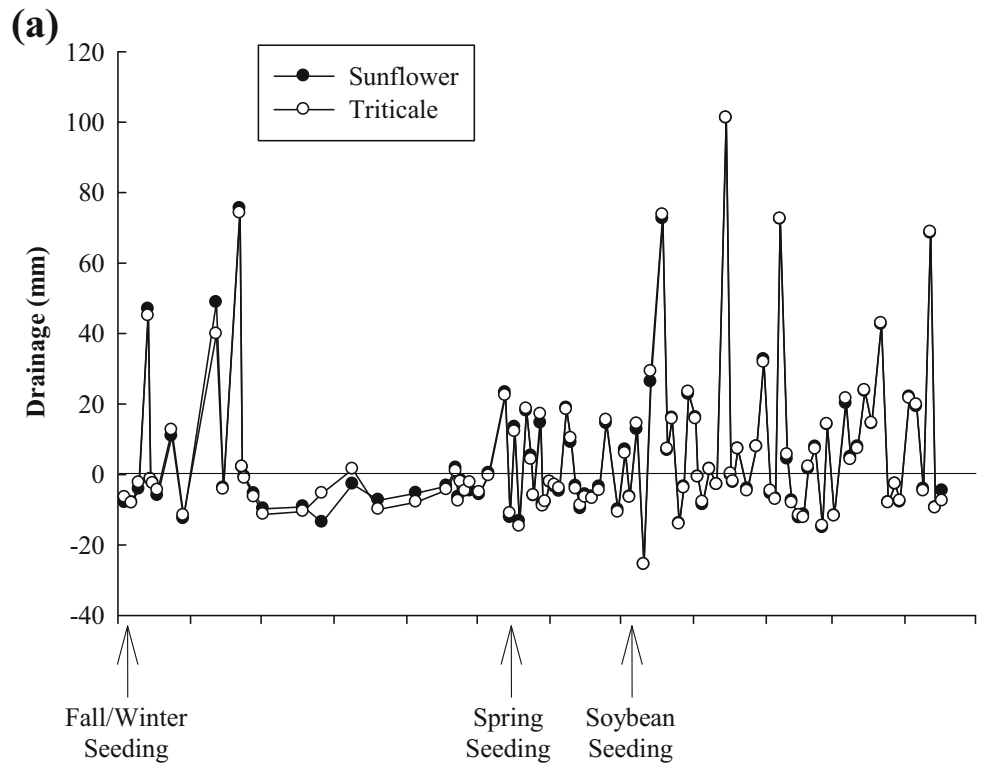

(b)

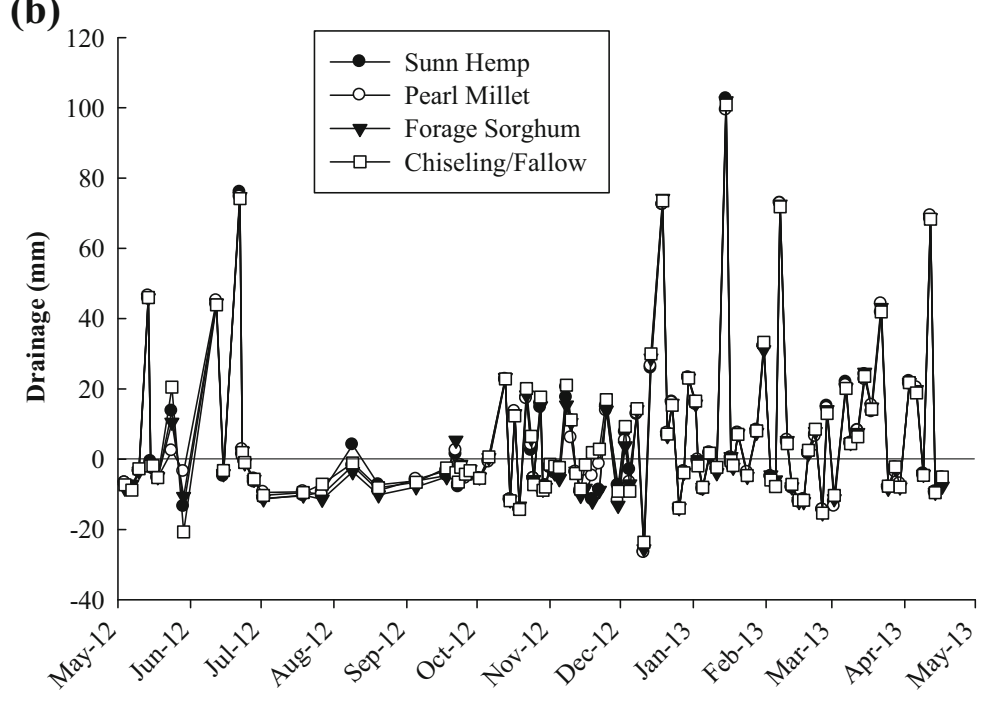

Rhodic Hapludox site, where N concentrations were mostly higher under sorghum than under pearl millet. The millet and sorghum $\mathrm{NO}_{3}-\mathrm{N}$ concentrations did not differ from Sunn hemp from November to early December but were lower thereafter.

\section{Discussion}

Considering that the soil was under continuous cropping for most of the year and the absence of $\mathrm{N}$ fertilization, the observed total $\mathrm{N}$ losses via $\mathrm{NO}_{3}{ }^{-}$leaching were relatively high, similar to or even higher than that observed in systems with $\mathrm{N}$ fertilization. For example, Wilcke and Lilienfein (2005) measured a N leaching rate of $23 \mathrm{~kg} \mathrm{ha}^{-1} \mathrm{y}^{-1}$ under a corn-soybean system in the Brazilian Cerrado, which was fertilized at an average annual rate of $70 \mathrm{~kg} \mathrm{~N}^{-1}$. In a Typic Hapludox soil, similar to our Rhodic Hapludox, $\mathrm{N}$ leaching from a corn crop fertilized with $120 \mathrm{~kg} \mathrm{ha}^{-1}$ ammonium sulfate over a 120-day period was $18.5 \mathrm{~kg} \mathrm{ha}^{-1}$ (Fernandes et al. 2006). Nitrogen losses observed in both experiments were clearly due, in large part, to the high rainfall during the experimental period (1906 $\mathrm{mm}$ ), especially at the beginning of winter and during summer, which resulted in high water drainage (overall mean of 642 and 
Fig. $5 \mathrm{NO}_{3}-\mathrm{N}$ concentrations in the soil solution as affected by fall/winter (a) and spring treatments (b), in the Typic Rhodudalf. Asterisks indicate significant difference by $\mathrm{F}$ test $(\mathrm{P}$ $<0.05)$. Vertical bars indicate the least significant difference by $\mathrm{t}$ test $(\mathrm{LSD})(\mathrm{P}<0.05)$

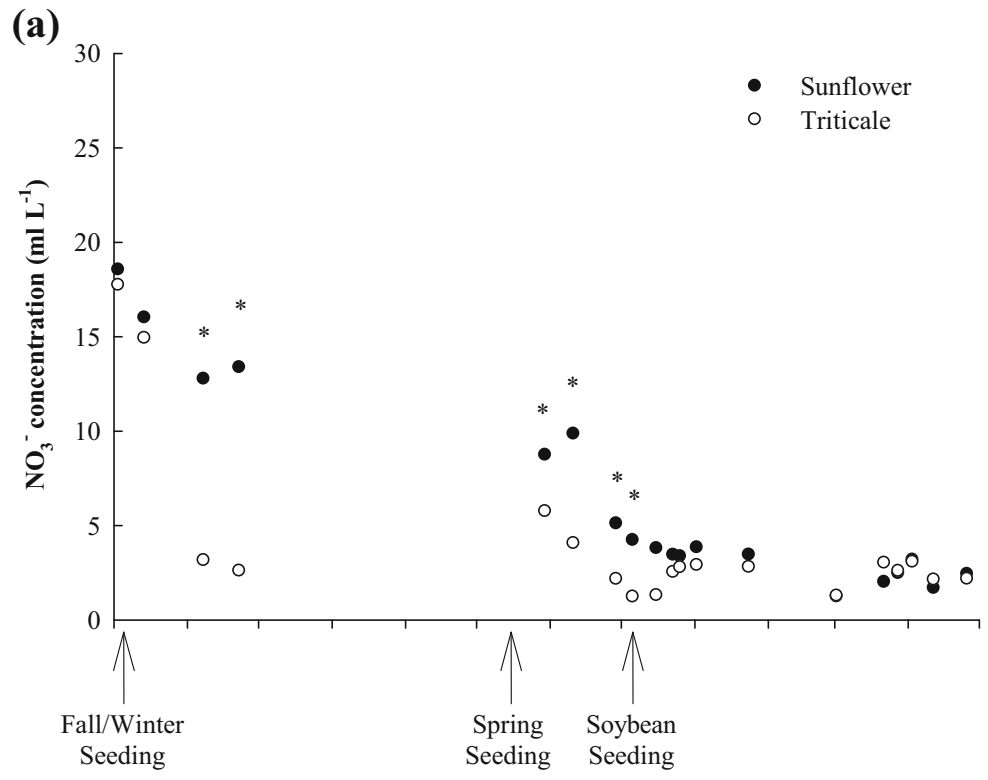

(b)

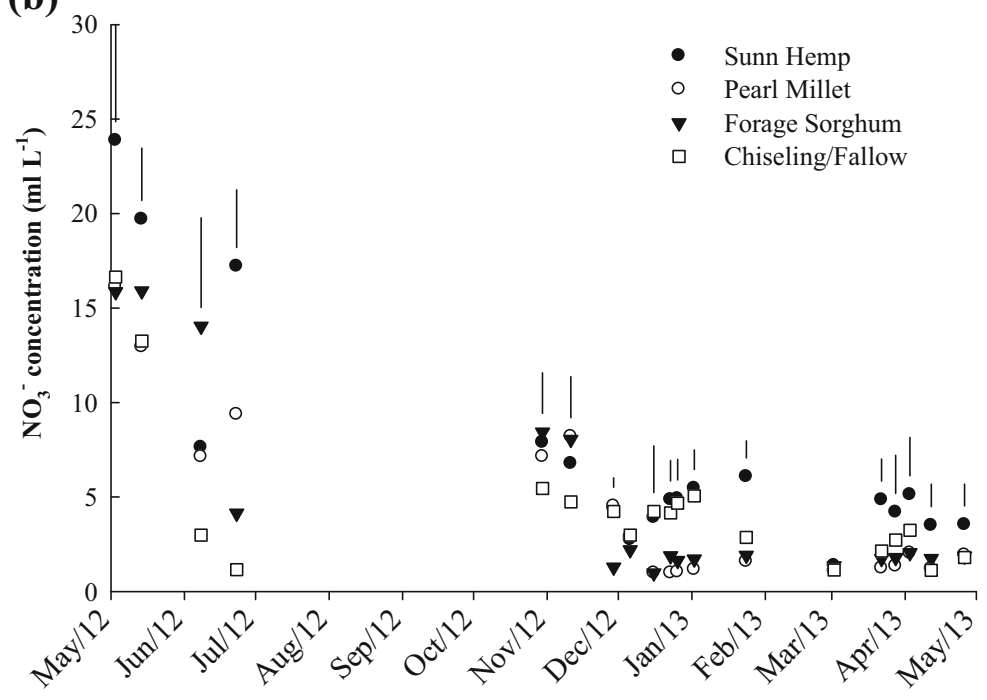

$556 \mathrm{~mm}$; Table 4), or from 29 to $34 \%$ of total rainfall. Fernandes and Libardi (2009) observed drainage from 54 to $81 \%$ during a corn crop in a typic Hapludox (820 $\mathrm{g} \mathrm{kg}^{-1}$ of sand, $20 \mathrm{~g} \mathrm{~kg}^{-1}$ of silt, and $160 \mathrm{~g}$ $\mathrm{kg}^{-1}$ of clay, at $0-0.4 \mathrm{~m}$ depth), a coarse-textured soil prone to greater drainage than the finetextured soils in the present study.

It is worth noting that nitrate leaching values may be higher than that observed, because the ceramic suction cups may show smaller $\mathrm{NO}_{3}{ }^{-}-\mathrm{N}$ content than observed with lysimeters (Zotarelli et al. 2007). However, in some occasions, these two sampling methods show similar results (Wang et al. 2012).
The experimental areas, particularly at the Rhodic Hapludox, are located in a predominantly flat terrain, and the soils have a high water infiltration rate (Prando et al. 2010), which results in high water drainage. Hence, the values observed in these experiments are within an expected range. In the Typic Rhodudalf, under chiseling/fallow, accumulated drainage was 45 to $62 \mathrm{~mm}$ higher than in the other spring managements due to a lower evapotranspiration during the brief fallow between tillage and soybean planting (Table 4).

Although data across the two experiment locations have not been statistically compared, it is clear that the $\mathrm{NO}_{3}{ }^{-}-\mathrm{N}$ content in the leachate was higher at Rhodic 
Hapludox (Fig. 3) than Typic Rhodudalf (Fig. 5). This result surely is related to a higher sand content in the Rhodic Hapludox, what provides lesser protection to soil organic matter and can contribute to a higher $\mathrm{N}$ mineralization (Six et al. 2002). On the other hand, the Typic Rhodudalf also showed smaller drainage than Rhodic Hapludox (Table 4), and consequently higher water retention and nitrate- $\mathrm{N}$ storage, what contributed to lower $\mathrm{NO}_{3}{ }^{-}-\mathrm{N}$ leaching in the Typic Rhodudalf.

Another difference between the experiments is the high $\mathrm{NO}_{3}{ }^{-}-\mathrm{N}$ content from December to February in the Typic Rhodudalf, what was not observed in the Rhodic Hapludox. This result can be related to a higher $\mathrm{N}$ accumulation after the fall/winter and spring crops in the Typic Rhodudalf(Table 3), associated with its higher sand content. Also, it can be observed that variations in $\mathrm{NO}_{3}{ }^{-}-\mathrm{N}$ contents are faster in the Rhodic Hapludox than in the Typic Rhodudalf, an evidence that the $\mathrm{NO}_{3}{ }^{-}-\mathrm{N}$ content at $0.8 \mathrm{~m}$ depth took longer to reflect what was happening at surface. In the Typic Rhodudalf, the fall/winter crops showed differences up to soybean planting (Fig. 5a), and spring crops showed differences along the year (Fig. 5b). This delay can be related to the higher clay content of the Typic Rhodudalf, i.e., this soil has more positive charges to retain $\mathrm{NO}_{3}{ }^{-}$(Harmand et al. 2010; Nakagawa et al. 2012).

Considering the fall/winter crops at both experiments, it is clear that grasses (grain sorghum, ruzigrass and triticale) scavenge more $\mathrm{N}$ than dicots (sunflower). Winter crops showed small differences in the Rhodic Hapludox (Fig. 3a), since they all are grasses, while in the Typic Rhodudalf sunflower resulted in higher $\mathrm{NO}_{3}{ }^{-}$ concentration than triticale (Fig. 5a). These results reflected in the total $\mathrm{N}$ loss of by leaching, because there was no difference among winter crops in the Rhodic Hapludox and $\mathrm{N}$ leaching was higher with sunflower than with triticale in the Typic Rhodudalf (Table 4). This may be related to a higher $\mathrm{N}$ content and lower $\mathrm{C} / \mathrm{N}$ ratio of the soybean residue when it was preceded by sunflower (data not shown). Also, besides the residues on the surface, the nitrogen remaining in the soybean root system and the higher activity of the microorganisms due to the increased $\mathrm{N}$ availability must be considered. Interestingly, triticale decreased soil solution nitrate concentration from one month after planting to the next spring, and then, a few days after soybean planting, $\mathrm{NO}_{3}{ }^{-}$concentrations were again similar to those under soybean following sunflower (Fig. 5a). Triticale apparently decreased the solution nitrate concentration for two reasons: the first, by the intense uptake of $\mathrm{N}$ and consequently higher $\mathrm{N}$ exportation by grains than sunflower (14.5 $\mathrm{kg} \mathrm{ha}^{-1} \mathrm{~N}$ of difference, data not shown); and second, by immobilization of $\mathrm{N}$ by straw, and possibly by roots as well, as shown by the continued low nitrate levels until soybean was planted.

In both experiments, generally $\mathrm{NO}_{3}{ }^{-}$concentration was higher under Sunn hemp than under pearl millet. Although millet has a high $\mathrm{N}$ uptake efficiency (Thivierge et al. 2015), in our case the residue $\mathrm{N}$ accumulation was lower in millet subplots (Table 3), excluding chiseling/fallow, and consequently the lowest amount of mineralizable $\mathrm{N}$ in the residue. The lower $\mathrm{N}$ accumulation in millet residue could explain, at least in part, the lower $\mathrm{NO}_{3}{ }^{-}$concentrations found in the soil solution. Menezes et al. (1997) proved that millet has a strong capacity to take up nitrate deeper than $1 \mathrm{~m}$, which makes it an interesting cover crop to manage nitrate leaching.

The decrease in $\mathrm{NO}_{3}{ }^{-}$concentration in soil solution with cover crops was higher for grasses than for legumes, probably because almost all $\mathrm{N}$ taken up by grasses comes from the soil, whereas legumes such as Sunn hemp obtain most of their $\mathrm{N}$ from biological $\mathrm{N}_{2}$ fixation, resulting in smaller changes in soil $\mathrm{N}$ concentration (Meisinger et al. 1991). This could explain the differences observed between systems with millet and Sunn hemp. This reasoning, however, does not apply to the results obtained for systems with forage sorghum. Growing forage sorghum in the spring, which, like millet, is a grass, resulted in $\mathrm{N}$ losses via $\mathrm{NO}_{3}{ }^{-}$leaching similar to those observed for Sunn hemp in the Rhodic Hapludox (Table 4). These losses, however, do not seem to be related to plant dry matter production or $\mathrm{N}$ accumulation. The $\mathrm{NO}_{3}{ }^{-}$concentrations in soil solution in the forage sorghum subplots were similar to those in the Sunn hemp subplots for the experimental period (Fig. 3b). This result leads to the hypothesis that the high $\mathrm{N}-\mathrm{NO}_{3}{ }^{-}$leaching in systems with forage sorghum results from such systems' cumulative effects, particularly regarding $\mathrm{N}$ accumulation in the soil. This hypothesis assumes SOM mineralization as the main source of the $\mathrm{N}$ lost via leaching in agricultural systems (Schneider and Haider 1992; Fernandes and Libardi 2009; Ghiberto et al. 2011), so that the higher the soil $\mathrm{N}$ content, the higher the potential for $\mathrm{N}$ leaching. Actualy, the highest total soil $\mathrm{N}$ content was found in forage sorghum and Sunn hemp subplots (data not shown), which supports this hypothesis. Right after 
soybean harvest in 2011/12, N storage in the soil down to $08 \mathrm{~m}$ deep under forage sorghum, Sunn hemp and pearl millet was $8.8,8.9$ and $8.2 \mathrm{Mg} \mathrm{ha}^{-1}$, respectively.

The root type of the species should also be considered, especially for the crops grown in spring. Sunn hemp, a legume with a tap root system, has lower root density and length than grain sorghum or millet, both grasses with fibrous root systems (Calonego and Rosolem 2010). The higher root production by millet and forage sorghum results in the formation of more biopores. These differences may extend to the $60-\mathrm{cm}$ soil layer and affect the root growth of soybean cropped in succession, which grows better when cropped following millet and forage sorghum (Pivetta et al. 2011). The higher residue $\mathrm{N}$ accumulation of the legume may explain the high $\mathrm{N}$ leaching. The differences between forage sorghum and millet, which have similar root systems, are most likely due to differences in soil $\mathrm{N}$ availability, as discussed above.

Considering the spring managements in the Typic Rhodudalf, despite the major differences in the $\mathrm{NO}_{3}{ }^{-}-\mathrm{N}$ concentrations during fall/winter, accumulated leaching was more affected by differences in $\mathrm{N}$ concentrations during the summer, since most of the rainfall (Fig. 1), and consequently drainage (Fig. 4b), occurred in this period. An example is chiseling/fallow, which had the lowest $\mathrm{NO}_{3}{ }^{-}-\mathrm{N}$ concentration up to soybean planting, but showed the second highest cumulative leaching because, during the soybean crop, $\mathrm{NO}_{3}{ }^{-}-\mathrm{N}$ levels were higher than those in the sorghum and millet rotations. The greatest loss of $\mathrm{NO}_{3}{ }^{-} \mathrm{N}$ by Sunn hemp was expected as a result of the higher $\mathrm{N}$ input by this species in the system, as shown by the high accumulation of $\mathrm{N}$ (Table 3) and low $\mathrm{C} / \mathrm{N}$ (data not shown) in the plant residues after desiccation. Considering that 57\% (Perin et al. 2004) to 65\% (Paulino et al. 2009) of the $\mathrm{N}$ in Sunn hemp comes from biological fixation, the larger $\mathrm{N}$ loss is compensated by a higher $\mathrm{N}$ input. Thus, the management chiseling/fallow results in higher $\mathrm{N}$ losses via nitrate leaching as compared with managements in which there is no $\mathrm{N}$ inputs by biological fixation.

It is worth noting that chiseling was done only in 2003 and 2009, so the most recent tillage had been done three years prior to data collection for this study. $\mathrm{N}$ losses would likely be greater in this treatment if the measurements occurred immediately after a tillage event, due to a higher organic matter mineralization. In a corn-soybean rotation with an average of $168 \mathrm{~kg} \mathrm{~N}^{-1}$ applied annually as swine manure, Rekha et al. (2011) found $\mathrm{NO}_{3}{ }^{-}-\mathrm{N}$ losses by leaching under chiseling and no-till of 18.2 and $10.4 \mathrm{~kg}$ $\mathrm{ha}^{-1}$, respectively. Paul and Clark (1989) suggested that under no-till, a higher $\mathrm{N}$ loss by leaching may occur due to the formation of continuous biopores in the soil resulting in increased water flow. However, this was not observed in this experiment. Considering that after chiseling the soil was always kept fallow from the harvest of winter crops to soybean planting, the results are also related to the absence of crops and the presence of weeds in this period. Thus, it is demonstrated that cover crops are a better soil compaction management strategy than occasional chiseling, since they are more effective in conserving soil $\mathrm{N}$, even when grown for a short period.

\section{Conclusions}

Nitrogen losses via $\mathrm{NO}_{3}{ }^{-}$leaching must be considered in cropping systems with no $\mathrm{N}$ fertilizer supplied since these losses can reach $33.6 \mathrm{~kg} \mathrm{ha}^{-1}$ year ${ }^{1}$.

In these systems, the magnitude of $\mathrm{NO}_{3}{ }^{-}$leaching is dependent of soil type, soil $\mathrm{N}$ content and $\mathrm{N}$ input by species in the system. Occasional chiseling in no-till soybean cropping systems is also a key factor, since it can result in higher leaching for at least three years.

The introduction of grasses with a vigorous root growth in the cropping system decreases $\mathrm{NO}_{3}{ }^{-}$concentrations in the soil solution, and it seems to be a good option, which deserves further consideration for incorporation into no-till soybean production systems.

When Sunn hemp is grown in the spring, $\mathrm{NO}_{3}{ }^{-} \mathrm{N}$ leaching is increased due to a higher $\mathrm{N}$ input into the system. Therefore it is important to alternate $\mathrm{N}$ fixing species with plants with high $\mathrm{N}$ scavenging capabilities, like millet, to decrease $\mathrm{N}$ leaching from agricultural production systems.

Acknowledgements The authors thank São Paulo Research Foundation (Fundação de Amparo à Pesquisa do Estado de São Paulo - FAPESP, grant 2011/02117-7) for financial support.

\section{References}

Allen RG, Pereira LS, Raes D, Smith M (1998) Crop evapotranspiration: guidelines for computing crop water requirements. FAO Irrigation and Drainage. Paper no. 56. FAO, Rome

Andrade Júnior AS, Silva JL, Bastos EA, Maciel GA, Ribeiro VQ (2010) Coeficientes de cultura da braquiária em cultivo 
solteiro e consorciado com milho (in Portuguese). In: Congresso Latinoamericano y Del Caribe de Ingenieria Agricola, 9.; Congresso Brasileiro de Engenharia Agrícola, 39. SBEA, Vitória (CD-ROM)

Askegaard M, Olesen JE, Kristensen K (2005) Nitrate leaching from organic arable crop rotations: effects of location, manure and catch crop. Soil Use Manag 21:181-188

Calonego JC, Rosolem CA (2010) Soybean root growth and yield in rotation with cover crops under chiseling and no-till. Eur J Agron 33:242-249

Cunha AR, Martins D (2009) Classificação climática para os municípios de Botucatu e São Manuel, SP. Irriga 14:1-11

Eaton AD, Clesceri LS, Greenberg AE (1993) Standard methods for the examination of water and wastewater, 18th edn. APHA, AWWA and WEF, Washington, DC

Errebhi M, Rosen CJ, Gupta SC, Birong DE (1998) Potato yield response and nitrate leaching as influenced by nitrogen management. Agron J 90:10-15

Fernandes FCS, Libardi PL (2009) Drenagem interna e lixiviação de nitrato em um Latossolo sob sucessão milho-braquiáriamilho, com diferentes doses de nitrogênio. R Bras Ci Solo 33:1163-1173

Fernandes FCS, Libardi PL, Carvalho LA (2006) Internal drainage and nitrate leaching in corn-black oat corn succession with two split nitrogen applications. Sci Agric 63:483-492

Ghiberto PJ, Libardi PL, Brito AS, Trivelin PCO (2011) Nitrogen fertilizer leaching in an Oxisol cultivated with sugarcane. Sci Agric 68:86-93

Hansen EM, Munkholm LJ, Olesen JE, Melander B (2015) Nitrate leaching, yields and carbon sequestration after noninversion tillage, catch crops, and straw retention. J Environ Qual 44: 868-881

Harmand J-M, Ávila H, Oliver R, Saint-André L, Dambrine E (2010) The impact of kaolinite and oxi-hydroxides on nitrate adsorption in deep layers of a Costarican Acrisol under coffee cultivation. Geoderma 158:216-224

Lara Cabezas WAR, Alves BJR, Urquiaga S, Santana DG (2004) Influência da cultura antecessora e da adubação nitrogenada na produtividade de milho em sistema plantio direto e solo preparado. Ci Rural 34:1005-1013

Lombardi Neto F, Belinazzi Júnior R, Lepsch IF, Oliveira JB, Bertolini D, Galeti PA, Drugowich MI (1994) Terraceamento agrícola. In: Bertolini D, Lombardi Neto F, Lepsch IF, Oliveira JB, Drugowich MI, Andrade NO, Galeti PA, Belinazzi Junior R, Dechen SCF (eds) Manual técnico de manejo e conservação de solo e água. v.4: Tecnologias disponíveis para controlar o escorrimento superficial do solo. CATI, Campinas, pp 11-35

Meisinger JJ, Hargrove WL, Mikkelsen RL, Williams JR, Benson VW (1991) Effects of cover crops on groundwater quality. In: Hargrove WL (ed) Cover crops for clean water. Soil and water conservation Society of America, Ankeny, pp 57-68

Menezes RSC, Gascho GJ, Hanna WW, Cabrera ML, Hook JE (1997) Subsoil nitrate uptake by grain pearl millet. Agron J 89:189-194

Mkhabela MS, Madani A, Gordon R, Burton D, Cudmore D, Elmi A, Hart W (2008) Gaseous and leaching nitrogen losses from no-tillage and conventional tillage systems following surface application of cattle manure. Soil Tillage Res 98:187-199

Nakagawa FK, Forti GBS, Alves ME, Lavorenti A, Miranda JH (2012) Estimating subsoil resistance to nitrate leaching from easily measurable pedological properties. Rev Bras Ciênc Solo 36:1491-1498

Ochsner TE, Albrecht KA, Schumacher TW, Baker JM, Berkevich RJ (2010) Water balance and nitrate leaching under corn in cura clover living mulch. Agron J 102:1169-1178

Paul EA, Clark FE (1989) Reduction and transport of nitrate. In: Paul EA, Clark FE (eds) Soil microbiology and biochemistry. Academic, New York, pp 147-162

Paulino GM, Alves BJR, Barroso DG, Urquiaga S, Espindola JAA (2009) Fixação biológica e transferência de nitrogênio por leguminosas em pomar orgânico de mangueira e gravioleira. Pesq Agropec Bras 44:1598-1607

Perego A, Basile A, Bonfante A, Mascellis R, Terribile F, Brenna S, Acutis M (2012) Nitrate leaching under maize cropping systems in Po Valley (Italy). Agric Ecosyst Environ 147:5765

Perin A, Santos RHS, Urquiaga SC, Guerra JGM, Cecon PR (2004) Produção de fitomassa, acúmulo de nutrientes e fixação biológica de nitrogênio por adubos verdes em cultivo isolado e consorciado. Pesq Agropec Bras 39:35-40

Pivetta LA, Castoldi G, Santos GP, Rosolem CA (2011) Crescimento e atividade de raízes de soja em função do sistema de produção. Pesq Agropec Bras 46:1547-1554

Prando MB, Olibone D, Olibone APE, Rosolem CA (2010) Infiltração de água no solo sob escarificação e rotação de culturas. R Bras Ci Solo 34:693-700

Reichardt K, Libardi PL, Meirelles NMF, Ferreyra FFH, Zagatto EAG, Matsui E (1977) Extração e análise de nitratos em solução de solo. R Bras Ci Solo 1:130-132

Rekha PN, Kanwar RS, Nayak AK, Hoang CK, Pederson CH (2011) Nitrate leaching to shallow groundwater systems from agricultural fields with different management practices. J Environ Monit 13:2550-2558

Ritchie JT (1998) Soil water balance and plant water stress. In: Tsuji GY, Hoogenboom G, Thornton PK (eds) Understanding options for agricultural production. Kluwer academic publishers, Dordretcht, pp 41-54

Schneider U, Haider K (1992) Denitrification and nitrate leaching losses in an intensively cropped watershed. J Plant Nutr Soil Sc 155:135-141

Sexton BT, Moncrief JF, Rosen CJ, Gupta SC, Cheng HH (1996) Optimizing nitrogen and irrigation inputs for corn based on nitrate leaching and yield on a course-textured soil. J Environ Qual 25:983-992

Silva RH, Rosolem CA (2002) Crescimento radicular de soja em razão da sucessão de cultivos e da compactação do solo. Pesq Agropec Bras 37:855-860

Six J, Conant RT, Paul EA, Paustian K (2002) Stabilization mechanisms of soil organic matter: implications for C-saturation of soils. Plant Soil 241:155-176

Soil Conservation Service (1985) National engineering handbook. Section 4. Hydrology. US Department of Agriculture, Washington, DC

Soil Survey Staff (2014) Keys to soil taxonomy, 12th edn. USDANatural Resources Conservation Service, Washington, DC

Soltani A, Sinclair TR (2012) Modeling physiology of crop development, growth and yield. CAB International, Wallingford

Swift RS (1996) Organic matter characterization. In: Sparks DL (ed) Methods of soil analysis. Part 3. Chemical methodsSSSA book series no. 5. Soil science Society of America 
and American Society of Agronomy, Madison, pp 10111069

Thivierge M-N, Chantigny MH, Seguin P, Vanasse A (2015) Sweet pearl millet and sweet sorghum have high nitrogen uptake efficiency under cool and wet climate. Nutr Cycl Agroecosyst 102:195-208

Wang Q, Cameron K, Buchan G, Zhao L, Zhang EH, Smith N, Carrick S (2012) Comparison of lysimeters and porous ceramic cups for measuring nitrate leaching in different soil types, new zeal. J Agric Res 55:333-345
Wilcke W, Lilienfein J (2005) Nutrient leaching in oxisols under native and managed vegetation in Brazil. Soil Sci Soc Am J 69:1152-1161

Williams JD, Wilkins DE, Douglas Jr CL, Rickman RW (2000) Mow-plow crop residue management influence on soil erosion in north-central Oregon. Soil Tillage Res 55:71-78

Zotarelli L, Scholberg JM, Dukes MD, Mufioz-Carpena R (2007) Monitoring of nitrate leaching in sandy soils: comparison of three methods. J Environ Qual 36:953-962 